\title{
The Phenomenon of the Skull Masks of the Lower Amur Petroglyphs
}

\author{
Zoya S. Lapshina* \\ Khabarovsk State Institute of Culture \\ 112 Krasnorechenskaia Str., Khabarovsk, 680045, Russia
}

Received 22.02.2016, received in revised form 04.04.2016, accepted 20.05.2016

\begin{abstract}
In the Lower Amur basin, there are numerous monuments of rock art. They are characterized by the predominance of skull masks. The semantic content of these artifacts allows to identify them as the main attributes of the rituals of the secret male unions. At the end of the Stone Age and the early Metal Age, the power of men and patrilineal kinship begin to prevail. The ancient model of the world was changed. The importance of the underground world and inevitability of death was dominating in the minds of the people. Authority was claimed through rituals with human sacrifices and cannibalism. The leader of the ritual was wearing a skull-type radiant mask. It was also drawn on the stones as the accumulation of power of the spirit-man-eater and called the "pile of cannibal". These facts are also observed in the rituals, folklore and petroglyphs of the Indians in Canada and North America. The theme of cannibalism is also present in the myths of the Amur indigenous peoples. The article describes the concept of the ideogram the "pile of cannibal" in the Lower Amur petroglyphs. The ideogram is presented as a three-part model of the world. The paper discusses the ideogram the "pile of cannibal" of Sikachi-Alyan and Sheremetyevo. This ideology and rituals could have been brought to America by the migrants from the Amur River basin.
\end{abstract}

Keywords: primitive art, Lower Amur, skull-type masks, petroglyphs of the Amur and the Ussuri rivers, worldview, cosmos.

DOI: 10.17516/1997-1370-2016-9-6-1320-1332.

Research area: culture studies.

\section{Introduction}

The lower Amur region is characterized by a variety of distinctive art forms. Their main feature are the skull-type masks. They have been observed on the embroidery, on household items of indigenous peoples, are the leading theme of ancient petroglyphs. The images of skulls on the stones and rocks have been attracting the attention of scholars for three centuries $\left(19^{\text {th }}-21^{\text {st }}\right.$ centuries.). The main position in explaining the origins of the phenomenon were diffusionism and convergent approach. B. Laufer saw Chinese influence in the art of the Amur region, A.F. Middendorf pointed to the similarities with the skull cult of the southern sea tribes. A.P. Okladnikov, not denying the influence of the south, showed local roots of ancient cultures; he also observed similar motives in the petroglyphs of North America, where they could have penetrated from the Amur basin (Okladnikov, 1971).

(C) Siberian Federal University. All rights reserved

* Corresponding author E-mail address: LapshinaZoy@gmail.com 


\section{Theoretical framework}

Numerous images of skulls indicates that this theme was predominating in the art of the archaic culture. Petroglyphs are the central part of the protected area where regular ritual actions took place in ancient times. The petroglyphs contain information about the important elements of the worldview of local tribes. The semantic content of skull images reveals the elements of the worldview of the Lower Amur River tribes at the end of the Stone Age and the early Metal Age. Persistent recurring of skull images in several petroglyphic monuments has become the basis for the art ideogram consisting of three parts. It has similarities in ritual and mythological culture of the North American Indians: in the central attribute of the secret male union rituals, "piles of cannibal". (Levi-Strauss, 1974; Segal, 1972; Okladnikova, 1989). Given the vectors of the exploration of the Americas, one of which crosses the Amur River basin, it is assumed that the key ideological positions of the "pile of cannibal" and its ideographic expression could have been brought by the migrants from the Lower Amur basin. In addition to fine art, the worldview with ideas of death and cannibal theme is reflected in the oral folklore of the Amur region (Sternberg, 2014; Shimkevich, 2012).

\section{Statement of the problem}

The concept is to determine art complexes in the Lower Amur petroglyphs that contain the "cannibal pile" ideogram and justify it as the model of the world at the end of the Stone Age early Metal Age.

Sociocultural and ritual atmosphere at the end of the Stone Age and beginning of the early Metal Age.

The end of the Stone Age is associated with important socio-cultural processes in tribal communities. Maternal family traditions begin to lose their value, secret male unions are formed. Their goal is to protect the rights of men who have come to the family through marriage (Eliade, 1989). In the future, they transform and become the social base for the formation of male authority in the transition to the father's family. Activities of the secret male unions were isolated and associated with initiation rituals and rites, which manifested the desire to intimidation, violence and suppression of the will of the tribesmen. Creating the cult of male power, they showed the continuity of the new form of ideology of the ancient cults of ancestors, fertility, demiurges through myths, rituals and symbols. A. Elkin noted this feature among Australian tribes: if a custom is not confirmed by a myth, then it is regarded as a work of man, and is not treated as an important one (Elkin, 1952: 183). This may explain the syncretism of the look and shape of attributes expressed in rituals, ceremonies, costumes, ceremonial masks, etc. Such scholars as M. Eliade, Levi-Strauss, D. M. Segal, E.A. Okladnikova and others describe and determine them. (Levi-Strauss, 1974; Segal, 1972; Okladnikova, 1989; Eliade, 1989).

The ideology of the members of secret societies at first had corporate character, and eventually began to spread. In the culture of the Indians of North America and Canada, the initiation rituals with human sacrifices and cannibalism were its central part. The research of F. Boas and his followers have shown that they were regularly held during winter holidays before the end of the $19^{\text {th }}$ century. The ritual was accompanied by myths and legends, special dances. The leader put on the costume and a special dance mask with skull features. Having the status of the principal dancer (the supreme spirit), he had the right to be in the costume with a hat and a skull mask. The halo around his head pointed to the connection with the upper world. His power was represented in the drawing on the rock as well: thus, radiant skull-like masks of 
petroglyphs had appeared. The series of skull-like masks in radiant headdresses were determined by E.A. Okladnikova among the petroglyphs of the North-West coast of North America. This was the sign of the supreme spirit-cannibal, the main dancer and the focus of his power was called the "pile of cannibal". (Okladnikova, 1989, 45-48). She showed its main features in the petroglyphs: 1. Mask with skull features (the depiction of cheekbones, round eye sockets, round nostrils instead of a nose, a protruding jaw, teeth, a big round or rectangular mouth). 2. Double outline of the masks: the depiction of the line of cheekbones by internal or external lines. 3. Radiant headdress. 4. Symbolic earring. 5. Scary appearance (bared teeth, an open mouth, a protruding tongue). 6 . Round big eyes with pupils and without them. 7. Separate (single) location on the rock. 8. Numerous three-point masks around the central image or on nearby rocks could correspond to the number of killed slaves or victims of the maneater (Okladnikova, 1989, 36-42).

Claude Lévi-Strauss shows in his works similar spirit masks of cannibals and "great healers", bear masks of the Tlingits of Alaska, the Iroquois of North America echoing the skull with teeth, a distorted face and round eye sockets (Levi-Strauss, 1974, 7 8). The concept of the "pile of cannibal" is capacious, the forms of its expression are numerous: oral legends, scenarios of rituals, sometimes it coincides with the totem poles of the North American Indians. Its threepart structure is invariant, it contains an image of the great spirit of the dancer, his assistant and ritual victims. They are considered in this study as a visual ideogram of the "pile of cannibal" with sacred properties.

Complexes of the ideogram the "pile of cannibal" in the Lower Amur petroglyphs

The iconographic description and semantic analysis of more than 50 skull masks allowed to determine fourteen complexes of this type. In
Sikachi-Alyan there are nine, four of the complexes have been preserved in total composition. The most important ones are those that are compactly arranged on one stone, there are three of them. In Sheremetyevo four complexes are described, two of them are complete. In Pereyaslavka (the Kiya river) the main character of the complex has been preserved. This work describes the seven complexes of Sikachi-Alyan and Sheremetyevo.

Sikachi-Alyan. The complex on the stone No. 13: 2, 3, 5 (Table 1:I). On the stone No. 13, the wide inclined surface is filled with drawings of masks. The top row of images is arranged into a single composition horizontally and is separated from the rest. Figure No. 2 is the central object of the composition: the mask with bright skull appearance. Eyes in three circular rims, the sockets. Square chin stands for the lower jaw. The mouth is shown with the tongue hanging out. These details give the impression of a terrible frightening force. The viewer sees the mask of the person who plays an important role in the sacred mystery. Nearby there is the mask No. 3 consisting of three holes. It is a memorial sign of the ritual's victim. On the right there is the mask No. 5. The outlines of the cheekbones and round eye sockets transmit the image of the skull. They are asymmetrical or distorted. The figure shows the features of the person subordinated to the will of others. In terms of iconography and composition, it the second most important figure, it serves as an assistant to the principal dancer.

Drawings of the top row of the stone block (No.13: 2, 3, 5) are considered as the ideogram of "the pile of cannibal" consisting of three parts (Table 1). The image of the supreme spirit-maneater is embodied in the mask No. 2, his assistant is depicted by the mask No. 5 , and between there is a place for victims of cannibalism: mask No. 3. The composition corresponds to the formula: "the principal dancer - the victim - the assistant". Below the complex there are several masks 
consisting of three holes. It is also the memorial of the victims of secret mysteries.

Sikachi-Alyan. The complex on the stone No. 55: 1, 2, 3 (Table 1:II). It consists of two main masks (1-2) and a contour of a poorly preserved mask. The images are located on the three adjacent faces of the stone No. 55. The central figure of the complex is the skull mask No. 1. The features of the skull are shown by means of eyes in round eye sockets, details of nose bones corresponding to the natural skeleton of the face. The plume on his head is quite remarkable, it conveys the presence of a ritual headdress on the person. Separate location on the face of the boulder also points out that the artifact belongs to the group of skull masks of supreme spirits - cannibals. Figure No. 2 is also a single image on the plane of the stone. It has stylized skull features. Round eyes in circles are placed in long pieces reminding of the Asian type of eyes. Cheekbones of the skull are surrounded by double arcs, the mouth by double bracket. Thus, the facial skeleton bones are shown. The mask bears the impression of sad emptiness. The third part of the complex is drawn on the left of the central mask on the third plane of the stone. When viewed from the top, it is located between the two masks. These are the features of the poorly preserved mask, the ritual's victim. The value of the complex is due to the compact arrangement of three main parts on one boulder. It repeats the sequence of parts of the complex on the stone No. 13: "the principal dancer - the victim - the assistant to the man-eater".

Sikachi-Alyan. The complex on the stones No. 59: 1, No. 68:1, 39:1 (Table 1:III). It is composed of images on three stones. The main argument of connecting them into one complex is the semantics of the content. The central character in appearance is the mask 1 on the stone No. 68 . This mask-skull with slanting empty eye sockets, nostrils, an open mouth and a tongue hanging out. There are no rays around the head, but on his right cheek there is a kind of a sacred earring. The second most important figure is represented by the mask No. 1 on the stone No. 59. This original skull-mask has the signs of a man and a beast. It corresponds to the appearance of female mythical characters: half-beast rozhanitsas of the celestial sphere. Features of the skull mask No. 59: 1 are highlighted by cheekbones, the lower jaw, nostrils and eyes in diamonds. This points at the connection with the world of spirits, and the proximity to the rituals of secret societies. The mask is interpreted as the mistress of underground world, the assistant spirit of the principal dancer of the winter holidays. The third part of the complex is presented by a mask without a contour (No. 39:1), consisting of two eye holes in circles and a mouth hole. This is the sacrificing part. The stone No. 39 has many similar masks, but they are poorly preserved. Perhaps this is a memorial stone where the features of killed victims were drawn. Thus, the complex consists of the skull mask with the tongue hanging out, his assistant spirit of anthropozoomorphic appearance and the mask of the victim.

Sikachi-Alyan. The complex on the stones No. 62: 1,3,4 a,b (Table 1:IV). The images of the complex occupy the basalt block with convex sides. The ritual complex occupies the middle horizontal part of the stone. Figure 1 is located on the long side. It is outlined due to the large size and brightness of the image. On the left, there is a small mask No. 3, made by three holes. Further there is a double mask No. 4 a, b. The central figure of the complex (mask No. 1) is the image of the skull mask. The headdress on the bare skull is outlined by an arc. The feature of the skull: two nostril holes instead of a nose; eyes in round eye sockets, mouth open. On the left an earing is stamped. Cheeks and chin, round eye sockets transmit the features of the dead head and make an intimidating impression. The mask-skull connects the features of ancestors-demiurges with 
Table 1. The ideogram the "pile of cannibal" on the Amur petroglyphs

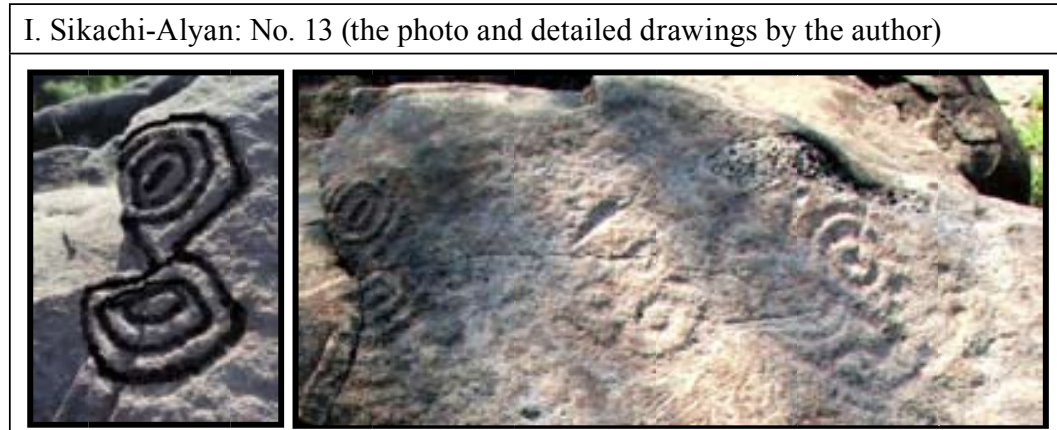

II. Sikachi-Alyan: No. 55 (author's photo)

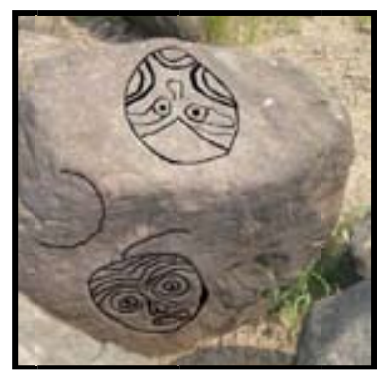

III. Sikachi-Alyan: No. 68, 59, 39 (Photo: Okladnikov, A.P.1971)

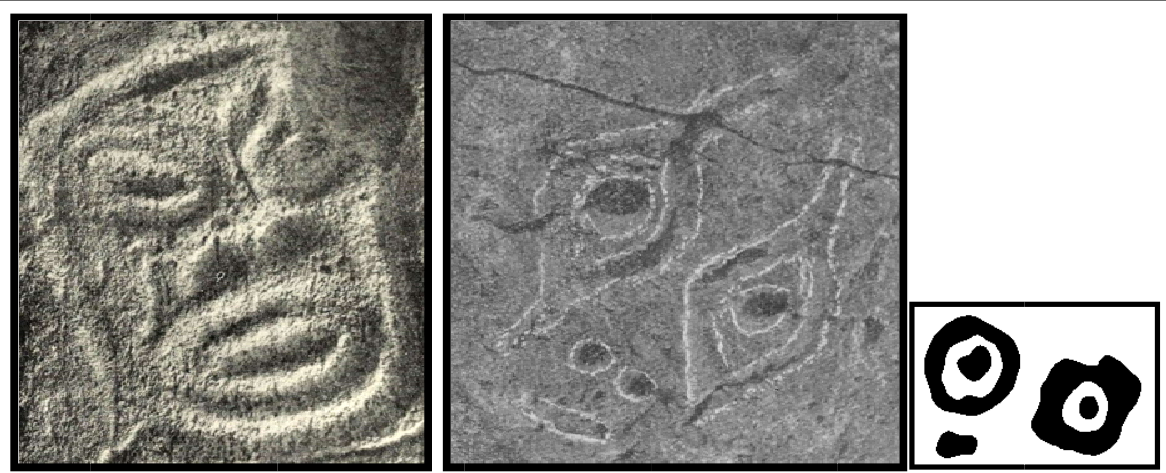

IV. Sikachi-Alyan: No. 62 (Drawings and photos: Okladnikov, A.P. 1971)

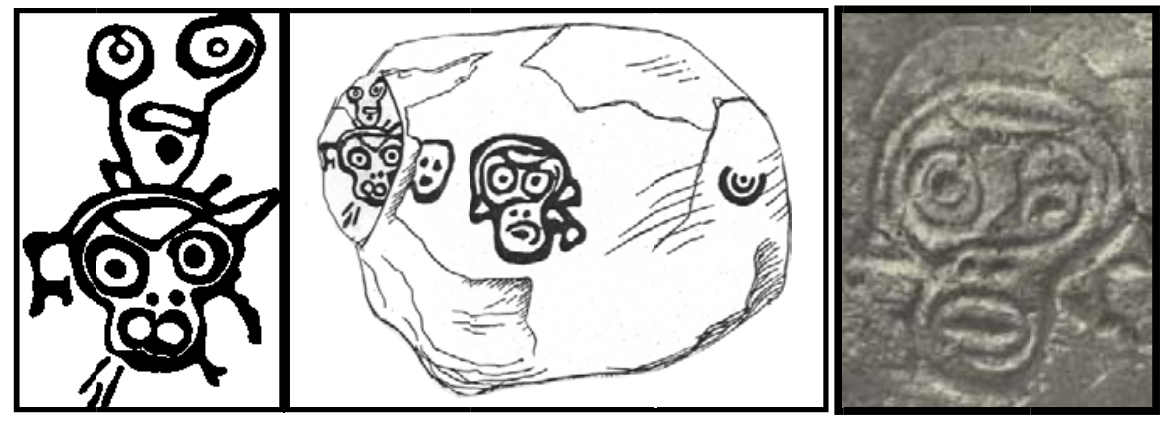


Table 1. The ideogram the "pile of cannibal" on the Amur petroglyphs (Continue)

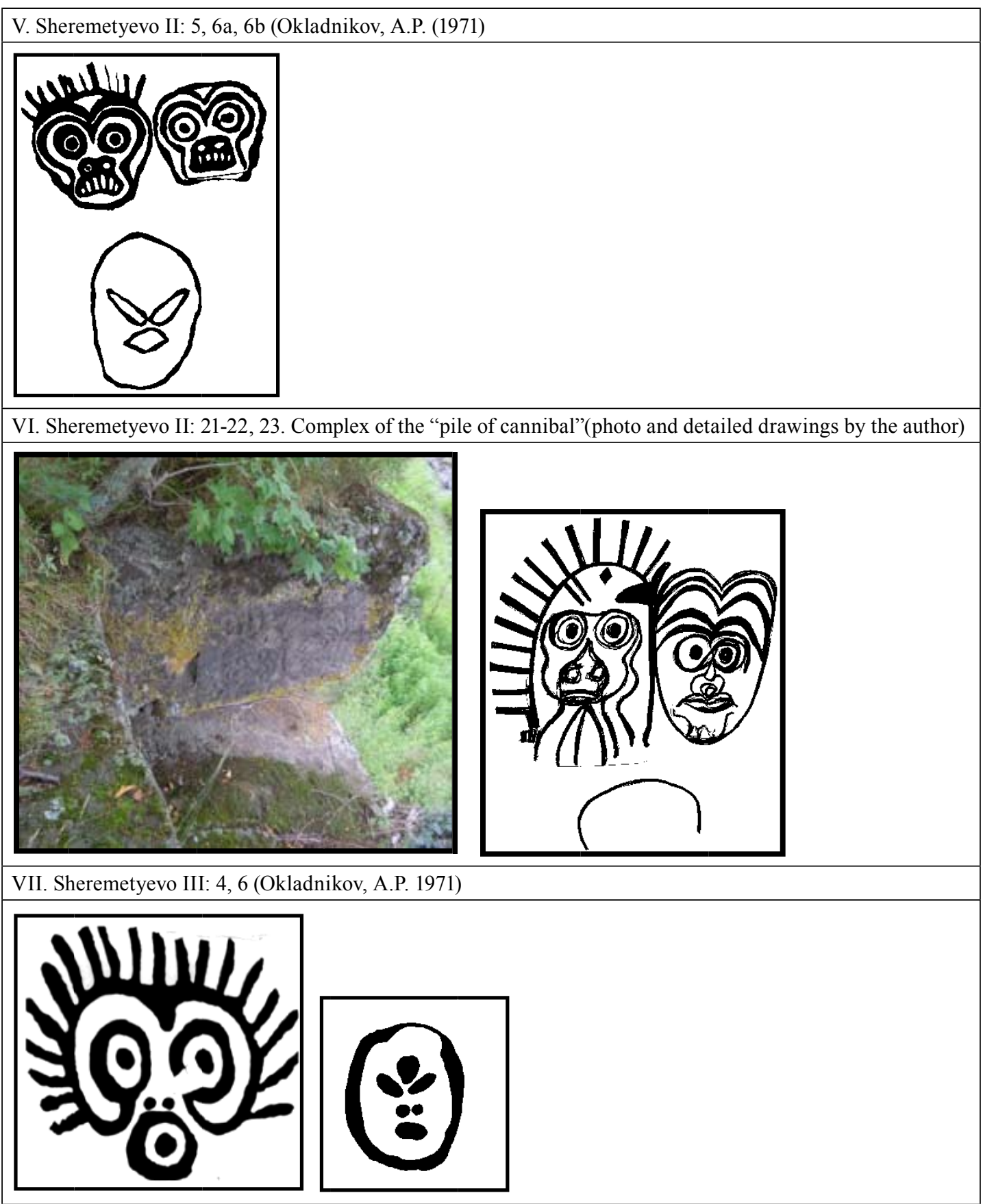


different eyes: the large one is associated with the sun, the small one is associated with the moon. At the same time, he is a formidable, energetic leader of the secret rituals of the transcendental nature. The headdress has no rays, they can be replaced by the sign of the ritual earring on the right side of the figure. The following figure, mask No. 3, has eyes and a mouth in the form of three holes. It is devoid of any features, has a small size and is located between the expressive characters. This points to the fact that the mask No. 3 is the symbol of the ritual's victim.

The third character, the mask No. 4 a,b is also bright and important, similar to the mask No. 1 , but it has a different function. The structure of the image $4 \mathrm{~b}$ contains a "snake line" (dotted line with the head of a snake). We interpret the images with the symbol of the snake as referring to the solar myths of the Lower Amur cosmos of the Stone Age (Lapshina, 2012). The mask No. $4 \mathrm{a}$ is the skull mask with outlined cheekbones and eyes in round eye sockets. On the forehead there is a symbol of angle. The upper mask (No. 4 b) seems to be "tied" to the lower one (No.4 a), it is a skull-type image with eyes in circles and an open mouth. The main features are the duality of the composition and the skull-type terrifying appearance. The characters demonstrate syncretism of the content: they re not only skull masks, but also the characters with solar symbols ("snake lines"). The second mask (No. 4 b) was previously interpreted as the assistant spirit of the principal character (No. 4 a) (Lapshina, 2012). Within the terms of this work, the images are interpreted as dual skull masks containing the symbols of previous mythological existence of celestial sphere in the images of birth giving deities (rozhanitsas). In the studied transition period from the Stone Age to the Metal Age they become the mistresses of the underground world. This is the reason of their terrifying skulltype appearance. Exploring the worldview of the tribes of Siberia and the Amur basin, ethnologists describe the journey of the shaman in the upper and lower worlds, transfer of the inhabitants of the upper world to the lower one. These metamorphoses correspond to social changes during the Bronze Age and early Iron Age (4000$3000 \mathrm{BC}$ ). The man in the society and the family begins to occupy a dominant position, while women are removed to the periphery of the public life, limited to the family sphere. As a result of these changes, strong powerful male heroes and deities appear in cosmological myths. Former ancestresses, coupled birth giving goddesses, mistresses of water, land or the taiga become the spouses of the master of the natural sphere or are removed from the upper world to the lower. They acquire skull-type features and become evil mistresses of the underworld (Anisimov, 1959). In the process of artistic understanding of the metamorphosis of mythical heroes, the characters with dual masks in appearance occur in the visual arts. They contain solar symbols in the form of "snake lines" in the pattern structure that suggest a link to the upper world, and at the same time, their appearance includes new features: an evil skull mask of the mistress of the underworld. The second character (No. $4 \mathrm{~b}$ ), the younger rozhanitsa, has turned into the assistant of the mistress of the underworld. Moreover, their mythological existence does not end here.

In the structure of the ideogram the "pile of cannibal" the mistresses of the underworld are given the place on the left side of the main character, the supreme spirit. This means that in the new structure of the world they occupy a place near the cannibal spirit and divide his functions. They represent the lower part of the world structure and, in fact, death. Their former function had not gone out of the consciousness of the community. Therefore, they embody a binary opposition of consciousness, the "life = death" 
dilemma. By absorbing the souls of the dead, they revive them. The dual mask is the second most important in the "pile of cannibal" structure and in the rituals of secret male unions.

The third part of the ideogram (the victim mask No. 3) is located between the main character (mask No.1) and the dual mask (No. 4 a,b). Next to the stone No. 62, on the stones No. 60 and No. 62 there are other masks of three holes circles by a contour and without it. This is the memorial of the ritual's victims and the evidence of its regularity. Thus, the composition on the stone No. 62 present the ideogram "the pile of cannibal".

The complex Sheremetyevo II: 5, $6 a, 6 b$ (Table 1::V). It is composed of coupled images No. $6 \mathrm{a}, 6 \mathrm{~b}$ and a separate image No. 5 located lower. The basis of the complex are dual masks. They are both skull-type: the dual contour outlines cheekbones, round eyes in circles; nostrils and detailed sticking out teeth. The skulls look quite natural/. On the mask No. 6a there is a plume headdress. This allows to identify the mask as the principal dancer of the rituals. The mask No. $6 \mathrm{~b}$ is interpreted as the former female character in the couple [8]. In the context of this work it is also determined as a female (spouse) and assistant of the cannibal priest. The third character is a large oval mask No.5. It contains of two empty slanting eyes and a mouth in the form of a segment. Everything is grouped in the center of the image. This technique and simplified face features create an impression of "lost essence" and humiliating internal emptiness. The main details of the face are drawn, but they do not show the individuality. This image corresponds to the third part of the "pile of cannibal", i.e. the mask of the victim of the initiation ritual.

This complex shows us a different version of the ideologem's composition. Unlike the complexes in Sikachi-Alyan, the formula is different: "the supreme spirit and the assistant are a couple, below them there is the victim".
The complex in Sheremetyevo II: 21- 22 and 23 (Table 1:VI). The petroglyphic drawing were discovered in 2009 and are high from the foot of the mountain, in a stone niche formed due to the fault of the rock. The niche consists of four walls. Coupled masks are located on the side plane, and the traces of the third image are observed on the horizontal area below them. The left image (the mask No. 21) occupies a dominating position, and the right image (the mask No. 22) occupies a subordinate, auxiliary position. The radiant mask No. 21 is peculiar due to its dome-like top, round eyes, outlined cheekbones and a bushy moustache. The nose is zoomorphic, the chin is wide. The character is wearing a headdress with a plume, on the left side there is a symbolic sign of an earring. These features allow to distinguish it as the supreme spirit-cannibal in the ritual headdress and skull-type mask with the features of the snake-dragon (round nostrils, a bushy moustache). On the forehead there are diamond symbols and two lines. They can refer to the male family symbols of the secret mail union. The symbol in the left part of the forehead is similar to the beak or head of a bird. The mask No. 21 is the central part of the "pile of cannibal". It combines fantastic, animal and human features, as well as the skull of the sacral ancestor with a radiant halo. The petroglyph shows a bright image of the ancestor, celestial being providing the leader of the ritual with high authority and transcendent properties. The mask No. 22 has an oval contour with a point (heart-shaped) top of the head and a wide chin. Round eyes are in circles, eye sockets. On the forehead there are parallel lines with a curve in the middle. In this composition, this is the assistant of the supreme spirit. In the rock art of the Pacific Ocean basin tribes, heart-shaped masks are referred to the period from the end of the Stone Age to Middle Ages (Okladnikova, 1989). The third part of the ideogram, the image of the victim, is located under the coupled masks on 
the horizontal plane of the stone niche. It is Figure No. 23 that has partially preserved the contour of a round mask. The complex is complete. This ideogram is peculiar due to coupled location of the main characters, the type of skull masks and anthropozoomorphic appearance of the supreme spirit with the radiant headdress. The content of the composition include the theme of the animal ancestor. The location of the victim under the main characters repeats the composition of the previous complex.

Complexc XIII. Sheremetyevo III: 4, 6 (Table 1:VII). The stone of this monument has only one single mask with a plume (4) and a bit higher there is a simple oval mask (6). Next to the Figure No. 4 there are traces of a mask that has not preserved. Here we can see two parts of the "complex of cannibal": the skull-type image with round eye holes in a circle and similar round mouth in a circle, a nose in the form of two holes. The whole top of the mask from one cheekbone to another is covered with the plume. The features of the skull mask and the plume allow to distinguish this mask as a ritual mask of the dancer-cannibal. The second image is a wide oval contour mask. Inside the contour in the centre there are an oval mouth and two nostril holes grouped together; above there are slanting eyes with an oval between them with a symbolic sign. On the one hand, the mask corresponds to the images of the ritual's victims, but on the other hand, the symbol on the forehead may indicate another status (the assistant of the supreme spirit). This complex is incomplete. Its other parts may be found later after cleaning this part of the rock from the moss.

Therefore, rock art demonstrates invariant features in iconography and in compositions of the ideogram the "pile of cannibal":

1. Images located in a specific way on a stone or a rock. Previously we have considered the images of the three-part composition.
2. The structure of the composition includes the main character in the center, its assistant and victim masks.

3. There are two typical composition types: in Sikachi-Alyan stones the victim mask is located between the main characters of the complex, and in Sheremetyevo stones the victim mask is located below the coupled images of the main characters.

4. The features of the supreme spirit: a headdress with a plume or an earring, outlined features of the skull, the tongue hanging out, terrifying appearance.

4. The features of the cannibal assistant: it often reminds the appearance of the main character, but does not have a headdress with a plume; sometimes it is the second skull mask but with asymmetric features. It can be represented by dual masks similar to the younger and older rozhanitsas.

5. The third part of the complexes is represented by simple masks without any symbols. They can have only three holes and no contour. Sometimes there are many of them on the same plane or on the adjacent stones. They are simple and do not have any social symbols. These are the images of "lost" and "dehumanized" souls of people who had become the victims of the evil ritual.

The wide distribution of the attributes of magical rituals of secret male societies suggests the long history of their existence and natural preservation of the echoes in other forms of art. One of them, folklore, allows to see the attitude to the studied ritual, its place in the collective consciousness and understanding of the world.

The theme of cannibalism in the world and Amur-Sakhalin cultural anthropology

Folklore sources can complement to the information on the rituals being studied and the main features of the characters distinguished on the petroglyphs. Claude Levi-Strauss in 
his book "The Way of Masks" determines the invariant elements of the Indian ritual mask: a wide-open mouth, saggy lower jaw exposing a huge tongue, protruding eyes. He calls this style of masks demonic (Levi-Strauss, 2000, 24). He gives the fragments of the songs that accompany the dance of the Salish masks: "Go away, the horrors, horrors with slaggy tongues, horrors with protruding eyes" (Levi-Strauss, 2000: 44). It is supposed to protect the Salish community from evil spirits, from the horror in the form of the dead head. All this means that the victims were brought to the supreme priest-cannibal by accident and by force.

Magic acts provided the priests-dancers with the great power and possession of sacred gifts. The gifts came from the other world (devil) forces. The heroes of myths were longing for these gifts, winning the supreme spirits. After receiving them, they preserved them in the family from generation to generation as a source of wealth and immortality, they became the symbols of the family. Claude Levi-Strauss observed that the Salish masks belonged to the clans of the high rank. The benefits of the family that possessed the masks were transferred by succession along with the relics. The masks that gave special privileges and power to the family, were depicted on various items. They became the means of identifying the family or its representative. Thus, the masks could have occurred on the "eternal" natural objects: stones and rocks.

F. Boas's works contain the descriptions of the emblems on the surface of the gables of houses and on the pillars in honour of the dead that belong to the members of the Indian families. Ordinary Indians of the Kwakiutl tribe understood the ritual of cannibalism as a terrible act that causes a terrible and forbidden effect. The victim of this ritual was almost ejected from the natural circle of ritual cycles. The one eaten by a cannibal could not have been buried in accordance with the rites of the tribe, because he was defiled by the contact with an unclean creature (man-eater) (Okladnikova, 1989: 129). Victims died not only physically, but also socially. Ceasing to be a member of the community, they fell out of the social environment, i.e. ritual and ceremonial support, and in this sense the ritual's victim was deprived of the human nature both in the living and the underground worlds.

Iu.E. Berezkin distinguished the criteris of the mythical winning hero in the myths of the Indians of Colombia (Uitoto), Costa Rica (Cabécar), Mesoamerica (Mayan Tarascans), Brazil (Nambikvara, Iranshe): rivalry adequate to the ritual ball game, the "one whose magical abilities are stronger, who stands hitting of the ball, or is able to reborn after he was sacrificed" wins (Berezkin, 1985, 44). Here three categories of rituals are listed: witchcraft, ball game and the ritual of initiation into the secret male union with human sacrifice and cannibalism. The composition of the myth in relation to the latter ritual reflects the understanding of the victim as a personality that completely disappears. Only cultural heroes with supernatural properties, who occurred to be a victim, can overcome the unnatural death.

The folklore contains the idea that man-eaters cause deviations from the rules and traditions, norms established by the Creator of life. M.O. Kosven describes the legend of the Sioux and the Navajo about the quarrel and separation of men and women into two groups. Men moved out of the village. Women having become Amazons, did all the male work and continued to give birth to children. But these children were not like the rest of the Sioux. After growing up, they had turned into giant cannibals who started to eat the humans of the tribe. The chief made the men return to the village. Afterward, the natural course of life was arranged (Kosven, 1947). The semantic emphasis of the legend is that a departure from the traditions 
and rules established by God leads to demonism. One legend, recorded by F. Boas, says that an Indian who was brought to a cannibal's house, kills the cannibal and its magic assistants. There he meets a woman whose feet were rooted to the ground. She helps to kill the man-eater, and gives him the attributes for winter ritual ceremonies of secret unions: masks, whistles, costumes from the bark, "the pile of cannibal", dance and song (Okladnikova, 1989). D.M. Segal noted that the Indians of the Kwakiutl tribe considered the "pile of cannibal" to be the main source of supernatural power of the main dancer of winter holidays; a kind of animate object that is not only dancing (rotating during the cannibal dance around its axis), but can also cause the death of the main dancer (Segal, 1972).

E.A. Okladnikova thinks that in the cultures of North American Indians the pile symbolized the basis of the world, the symbols of cannibalism of secret unions demonstrate the idea of life changed by death. The act of drawing the pictures on the stone is similar to arranging a totem post, the symbol of stability of the world (Okladnikova, 1989: 131). The leader of the ritual (the supreme spirit) showed his participation in the change of life to death, he was "brining death" and thus he outlined his supreme power among his tribesmen.

The rituals close in meaning and value are also typical for the cultures of East Asia. The ancient tradition of human sacrifice among the Ainu of the Japanese archipelago was mentioned by the Russian scientist M.M. Dobrotvorsky in the 70 s of the $19^{\text {th }}$ century. He found in the etymology of the ritual terms the procedure of cutting the human body. The Sakhalin Ainu named the villages on the island Hokkaido, where secretly from the Japanese, these rites were carried out (Dobrotvorsky, 1875). EA Kreinovich determined the signs of archaic human sacrifices in the terms and elements of the script of the bear festival of the Nivkhs. The bear in the course of the ritual development substituted the human (Kreinovich, 1973: 126, 194, 210-211). He observed the custom when the Nivkhs in order to save a newborn baby had the custom when the mother was forced to bite off and swallow the little finger of the baby's left hand. Especially, if in the family the boys died often. It was believed that "the soul lives in the left little finger of the baby. Biting the left little finger of the left of the newborn, the Nivkhs wanted to show evil spirits - the enemies of the people, that the child has been already eaten, that he was no longer alive" (Kreinovich, 1973: 344). The Amur Nivkhs thought that there are evil spirits called "unrk", the man-eaters, and they were very afraid of them (Kreinovich, 1973: 337). The folklore material of the Nivkhs recorded by L.Ia. Sternberg in the period from 1891 to 1897 on Sakhalin and in the Amur basin, contains the theme of cannibalism refraining in many legends. Heroes are looking for missing relatives, and encounter cannibals on their way. In the poem "The Lonely Woman", the female character is looking for her older brother, and on the way she meets an old man who threatens her: “... I'll grab you and tie with a thick chain, then I'll kill you; then I'll eat your meat not leaving a piece!". Further along the road, she meets old cannibals and runs away from them. Returning home with her brother, she hears a woman crying: "Bring me only human flesh, I don't want any animal meat". The heroes of the legend fight the cannibals (Sternberg, 2014, 61-78). P.P. Shimkevich in the late $19^{\text {th }}$ century recorded the Nanai tale about a wife, who is looking for her kidnapped husband. Than Hoto, the man-eater, comes to take her away, she resists. Hoto calls his wife for help and warns that this woman is strong, she has iron hair, and asks her to grab an iron bag. The two cannibals captured the woman having put her in an iron bag and dragged under the ground, where she was rescued by her husband (Shimkevich, 
2012, 75-83). The ethnic cultures of the Amur hitherto have preserved the tradition of the ritual post. One of them refers to family rituals: it is the post of gusi tora (mother's brother) in the Nanai hut. S.V. Ivanov interprets the semantics of the images on it as a three-part structure of the world, i.e. the image of the world tree (Ivanov, 1953, 238). Another category relates to the public religious and ritual life: a log for the bear festival in the Nivkhs customs; the Ulchis music log for hitting to accompany the bear festival; the shaman post. The latter is a ritual shamanic tree with the symbols of the world tree. The notion of the post as the center of the world, the ritual, the house extends to all spheres of life.

\section{Conclusion}

The foregoing shows the organic connection between a separate category of petroglyphs and the real rituals of the secret male unions. The main attribute of the rituals the pile of cannibal" - performs the functions of the cosmos model and becomes the basis for determining the worldview at the end of the Stone Age and the Metal Age. In this universe three archaic parts are preserved. The former understanding of the world contained the main upper sphere and the solar-astral mythology. The sources that had been investigated determined the universe with the dominant lower world. Petroglyphs reflected the leading theme of the lower sphere: death, hell and its formidable inhabitants. The masks of the Amur region preserved the mythology of birth giving deities transfer from the upper sphere to the lower one. Such are the metamorphoses of the mythology and rituals of transition from the matrilineal to patrilineal system of kinship.

\section{References}

Anisimov, A.F. (1959). Cosmologicheskie idei narodov severa [Cosmological ideas of the peoples of the North]. Moscow-Leningrad, $106 \mathrm{p}$.

Berezkin Iu.B. (1985). Maniokovoe derevo: proiskhozhdenie tropicheskogo zemledeliia v Amerike [Tapioca tree: the origin of tropical agriculture in America]. In Nature, (10), 39-46.

Dobrotvorsky, M.M. (1875). Ainsko-russkii slovar [Ainu - Russian Dictionary]. Kazan, 582 p.

Eliade, M. (1998). Shamanizm. Arkhaicheskie tekhniki ekstaza [Shamanism. Archaic techniques of the trance]. Transl. from English. K.Bogutsky, V.Trilis. Sofia, 384 p.

Elkin, A. (1952). Korennoe naselenie Avstralii [Indigenous Australians]. Moscow, 254 p.

Ivanov, S.V. (1952). Arkhitekturnyi ornament narodov Nizhnego Amura [The architectural decoration of the peoples of the Lower Amur]. MAE collection (XV). Moscow-Leningrad, 234-290.

Kosven, M.O. (1947). Amazonki. Istoria legend [The Amazons. The history of legends]. In Sovetskaia etnografia [Soviet ethnography], 3, 3-32.

Kreinovich, E.A. (1973). Nivkhi. Zagadochnye obitateli Sakhalina i Amura [The Nivkhs. Mysterious inhabitants of Sakhalin and Amur]. Moscow, Nauka, 495 p.

Lapshina, Z.S. (2012). Arkhaicheskaia model mira v naskalnikh risunkakh Amura i Ussuri [ The archaic model of the world in the stone drawings of the Amur and the Ussuri]. Khabarovsk, KhSIAC, $212 \mathrm{p}$.

Levi-Strauss, K. (1974) .Koldun i ego magiia [The Sorcerer and his magic]. In Nature. (7), 86 - 91. (8), 88-97.

Levi-Strauss, K. (2002). Puti masok [ The Way of Masks]. Trans. by A.B. Ostrovsky. Moscow, $97 \mathrm{p}$. 
Okladnikov, A.P. (1971). Petroglify Nizhnego Amura [Petroglyphs of the Lower Amur]. Leningrad, Nauka, 335 p.

Okladnikova, E.A. (1989). Zagadochnye lichiny Azii i Ameriki [Mysterious masks of Asia and America]. Novosibirsk, Nauka, 168 p.

Segal, D.M. (1972). Mifologicheskie izobrazheniia u indeitsev Severo-Zapadnogo poberezhia Kanadi [Mythological images of the Indians of the North-West Coast of Canada]. In Rannie formy iskusstva [Early forms of art]. Moscow, 321-372.

Shimkevich, P.P. (2012). Materialy issledovaniia shamanizma u Gol'dov [Materials of study of Shamanism among the Golds]. Moscow, Librokom, $2^{\text {nd }}$ edition, $168 \mathrm{p}$.

Sternberg, L.Iu. (1908). Materialy po izucheniu giliakskogo iazyka i fol'klora [Materials of the study of the Gilyak language and folklore]. 1. Obraztsy narodnoi slovestnosti [Samples of folk literature]. Part 1. Epos [Epos]. Saint Petersburg, Publishing House of Imperial Academy of Sciences, $252 \mathrm{p}$.

\section{Феномен искусства череповидных личин петроглифов Нижнего Амура}

3.С. Лапшина

Хабаровский государственный институт культуры Россия, 680045, Хабаровск, ул. Краснореченская, 112

В бассейне Нижнего Амура расположены памятники наскального искусства. Основной их признак-череповидные личины. Семантическое содержание артефактов позволяет расценивать их как атрибуты ритуалов тайных мужских союзов. На рубеже каменного века и ранних металлов в социумах утверждалась власть мужчин и патрилинейное родство; была изменена древняя модель мира; в сознании закреплялась значимость нижней сферы и неизбежность смерти. Власть утверждалась ритуалами с человеческими жертвоприношениями с каннибализмом. На руководителе мистерий была маска-череп в лучах, её наносили на камни как средоточие силь духа-людоеда и называли «столбом людоеда». Это прослежено в обрядах, фольклоре и петроглифах индейцев Канады и Северной Америки. Тема людоедства содержится и в мифах аборигенов Амура. В статье изложена концепџия идеограммы «столб людоеда» в петроглифах Нижнего Амура. Она трактована как модель мира. В Америку эти традиции могли занести мигранты из района Амура.

Ключевые слова: первобытное искусство, Нижнее Приамурье, череповидные личины, петроглифы в бассейнах рек Амур и Уссури, картина мира, Вселенная.

Научная специальность: 24.00.00 - культурология. 